\title{
The Effect of Problem Based Learning (PBL) Model and Jigsaw Type of Cooperative Learning Model with Prezi Aid on the Students' Learning Outcome
}

\author{
Sahat Renol HS ${ }^{1}$, Soetarno Joyoatmojo ${ }^{1}$, Mintasih Indriayu ${ }^{1}$ \\ ${ }^{1}$ Universitas Sebelas Maret, Surakarta, Indonesia
}

\begin{abstract}
PBL model and jigsaw type of cooperative learning model with prezi aid are two learning models that can increase the students' ability in solving problem, improving students' activeness, improving the students' ability in technology use and improving the learning outcome. This research aims to find out the difference of economic learning outcome between problem based learning model with prezi aid and jigsaw type of cooperative learning with prezi aid. This study was a quantitative research with experimental method. The population of research used in this research was all students of Public Senior High Schools in Surakarta. The sampling technique used was random sampling. The sample of research consisted of 66 students: 32 10th IIS4 graders of SMA 5 Surakarta as experiment class using problem based learning (PBL) model with Prezi media aid, and 34 10th IIS-2 graders of SMA Negeri 7 Surakarta as control class using Jigsaw type of cooperative learning model with Prezi media aid. The result of research showed that there was a significant difference of learning outcomes between the students using problem based learning (PBL) model with Prezi media aid and those using Jigsaw type of cooperative learning model with Prezi media aid. It could be seen from the significance value (Sig) lower than significance level $=0.05(0.038<0.05)$ or $($ Fobs $=4.477>$ Ftable $=3.98)$.
\end{abstract}

Keywords: problem based learning; jigsaw; prezi

\section{INTRODUCTION}

Nowadays, world develops very rapidly. The world development rate contributes to the development of other sectors according to its time, one of which is education sector. In order to keep up to date, education should change as well. Many countries in the world begin to realize the importance of education in transformation era and time development. They mention that education problem is the complex issue.

Education is the key to a nation's success in which it plays a very important part in creating smart, high-quality, moral and character society. In UUSPN No. 20 [1], mention that: "National education is a conscious and planned attempt of realizing learning circumstance and learning process to make the students develop their potency actively in order to have spiritual religious power, self-control, personality, 
intellectuality, noble character, and skill they, the society, the nation, and the state need".

The advance of Indonesian can be achieved through organizing a good education through the attempt of improving education expectedly improving Indonesian's dignity and prestige. The improvement of education quality has been done through improving the quality of learning such as: curriculum reform, learning model development, evaluation system change, and etc.

The good quality of learning can be seen from the good learning outcome. Learning outcome so far still becomes a problem often becoming the topic of conversation among parents, students, and expert. From the result of national examination in 2014/2015, data obtained from BALITBANG KEMDIKBUD (www.balitbang.kemdikbud.go.id) shows that the mean score of national exam for Surakarta city is still low particularly in economic subject (65.44).

TABLE I. NATIONAL EXAM SCORE OF STUDENTS IN PUBLIC SENIOR HIGH OF SURAKARTA CITY IN THE SCHOOL YEAR OF 2014/2015

\begin{tabular}{|c|c|c|c|c|c|c|c|}
\hline $\begin{array}{c}\text { Exam } \\
\text { Score }\end{array}$ & Indonesian & English & Math & Economic & Sociology & Geography & Total \\
\hline Category & $\mathrm{B}$ & $\mathrm{C}$ & $\mathrm{B}$ & $\mathrm{C}$ & $\mathrm{C}$ & $\mathrm{C}$ & $\mathrm{C}$ \\
\hline Mean & 80.97 & 67.42 & 70.05 & 65.44 & 69.64 & 61.76 & 415.28 \\
\hline Lowest & 35.4 & 20.4 & 7.7 & 20 & 24.5 & 20 & 200.9 \\
\hline Highest & 96 & 96 & 97.5 & 97.5 & 95.9 & 87.8 & 536 \\
\hline $\begin{array}{c}\text { Standard } \\
\text { Deviation }\end{array}$ & 8.09 & 14.67 & 14.67 & 14.17 & 12.66 & 12.31 & 67.35 \\
\hline
\end{tabular}

Source: Research and Development Division of Education and Culture Ministry

The low learning outcome is likely due to the less effective learning applied at school. Meanwhile, education will achieve its objective when the learning runs with effective teaching. It is in line with Asif and Imran [2] stating that education quality is dependent on its learning quality. In learning, students are required to solve practical problem that can generate learning experience for them. For that reason, an appropriate learning strategy should be chosen.

It is important for teacher, as an educator, to understand that learning process is a multi-directional communication process between students, teacher, and learning environment. Therefore, learning should be organized in such a way that the learning effect will be obtained leading directly to the change of behavior as formulated in the learning objective [3]. The selection of appropriate learning strategy will lead to the change of behavior encouraging the students to be active. Therefore, the teachers' role is required to implement it.

Teacher-centered learning will only make the students passive, in either asking question or in expressing opinion during learning process. Learning process will tend run rigidly as it is limited to the knowledge transfer process. Learning building on teaching purpose rather than on students' need will eventually make the students saturated and bored. Otherwise, teacher serves as facilitator in learning activity inviting the students to participate both physically and mentally. The students will ask question and express opinion actively during learning process.

In reality, the low learning outcome shown in National Examination score of Senior High School students is due to ineffective and inefficient learning process at 
school. It can be seen from the less maximal interaction between students and teachers and between students in learning process. Teachers still often use lecturing method thereby making the students less active in learning process. It makes the learning teacher-oriented rather than students-oriented. Teachers have not really understood the existing learning model and it impacts on the less effective learning so that students' participation in creating active learning has not been achieved.

There are many active learning model involving students. Prince [4] states that the active learning model is manifested in collaborative learning, cooperative learning, problem based learning, and project based learning.

This research focused on the problem-based learning and jigsaw type of cooperative learning model. Wulandari and Surjono [5] suggest that problem based learning is a progressive active learning and unstructured problem-centered learning approach used as the starting point in the learning process. Problem-based learning model can make the students active there by contributing to the improved learning outcome of students [6]. Isjoni explains jigsaw type of cooperative learning as a type of learning expecting the students help each other in mastering the material and making the students more active. The students involved in jigsaw type of cooperative learning can improve their learning achievement and have better and more positive attitude to the learning [7].

In this research, the author applied problem based learning and jigsaw type of cooperative learning models in the presence of learning media aid. The use of media in learning model application is expected to support learning process and to create an active learning circumstance. The media used as learning media in this research is prezi.

It is expected that problem based learning model with prezi aid and jigsaw type of cooperative learning model with prezi aid can increase the students' ability of solving problem, improving the students' activeness and can improve the students' ability in using technology and improving economic learning outcome at Senior High School (SMA) level. The objective of research is to find out the difference of economic learning outcome between students using problem-based learning model with prezi aid and those using jigsaw type of cooperative learning model with prezi aid.

\section{METHOD}

Research method employed in this research was quantitative one. The type of research used was quasi-experimental one as it was impossible for the author to control all independent variables affecting the dependent one.

This research was designed to find out the effect of independent on dependent variables, including:

1. Problem-based learning model and jigsaw type of cooperative learning model with prezi aid as independent variables

2. Students' learning outcome as dependent variable. 


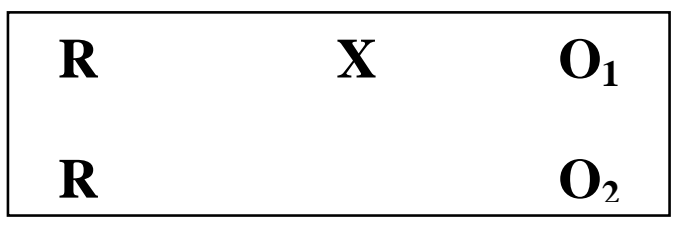

Figure 1. Research Design

This research design was intended to find out the effect of learning using problem-based learning model and jigsaw type of cooperative learning model with prezi aid on the students' learning outcome. The research design employed in this research was the post-test only control group design.

The population of research was all Public Senior High Schools (SMA) existing in Surakarta City, consisting of 8 schools. The sample of research consisted of 3 schools: SMA Negeri 5 as experiment class, SMA Negeri 7 as control class and SMA Negeri 2 as instrument trial class, from each of which 1 class was taken. The sampling technique used was random sampling one.

Techniques of collecting data used in this research were documentation and test. Documentation technique was used to obtain data of students' score in order to find out whether or not the sample taken from population had been distributed normally and homogeneously. Test technique was used in this research included objective test with a multiple choice form with 4 alternative answers.

The research instruments used were validity test, reliability test, item difficulty level test, and item variance. It was intended to find out whether or not the instrument had met the requirement as instrument of collecting data in this research.

Technique of analyzing data used in this research was one-way anava test aiming to examine the significant effect of two learning models on the students' learning outcome. To use analysis, analysis prerequisite test should be met first. The analysis prerequisite test in this research includes normality and homogeneity tests.

\section{RESULT AND DISCUSSION}

Before the data of research used for hypothesis testing, the prerequisite analysis test was conducted including data normality and homogeneity tests.

\section{Normality Test}

This research employed Shapiro Wilk normality test at significance level $(\alpha)=$ 0.05. If the significance level is more than 0.05 ( $\mathrm{Sig}$. > 0.05), the data will derive from the normally distributed population, while if it is less than 0.05 (Sig. < 0.05), the data will not distributed normally. 
TABLE II. DATA NORMALITY TEST

\begin{tabular}{|lr|r|r|r|r|r|r|}
\hline \multirow{2}{*}{\multicolumn{2}{|c|}{ Learning Model }} & \multicolumn{2}{|c|}{ Kolmogorov-Smirnov ${ }^{\mathrm{a}}$} & \multicolumn{3}{c|}{ Shapiro-Wilk } \\
\cline { 2 - 8 } & Statistic & \multicolumn{1}{c|}{ Df } & \multicolumn{1}{c|}{ Sig. } & Statistic & \multicolumn{1}{c|}{ df } & \multicolumn{1}{c|}{ Sig. } \\
\hline Learning & PBL & .078 & 32 & $.200^{*}$ & .972 & 32 & .570 \\
Outcome & JIGSAW & .108 & 34 & $.200^{*}$ & .970 & 34 & .467 \\
\hline
\end{tabular}

*. This is a lower bound of the true significance.

a. Lilliefors Significance Correction

Considering table II sing Shapiro-Wilk test using SPSS 22 software, it can be found Sig.value $>0.05$. It means that entire data derives from normally distributed population.

\section{Homogeneity Test}

This research employed homogeneity test, Levene Statistic, available in SPSS 22 software.

TABLE III. DATA HOMOGENITY TEST

\begin{tabular}{|c|c|c|c|}
\hline \multicolumn{4}{|l|}{ Learning Outcome } \\
\hline Levene Statistic & df1 & df 2 & Sig. \\
\hline .228 & 1 & 64 & .635 \\
\hline
\end{tabular}

Considering table III using Levene Statistic, it can be found that learning model variable has significance (Sig. > 0.05), meaning that the data is homogeneous. The normally distributed and homogenous data was then tested using variance analysis (Anava) test.

\section{Hypothesis Testing}

Hypothesis testing is conducted using one-way variance analysis with SPSS 22 software. The criteria of hypothesis testing in this research is that when significance level is less than 0.05 (Sig. $<0.05$ ), $\mathrm{H}_{0}$ is not supported and $\mathrm{H}_{1}$ is supported, and vice versa. 
TABLE IV. ONE-WAY ANAVA TEST

\begin{tabular}{|l|r|r|r|r|r|}
\hline Learning Outcome & \multicolumn{7}{|c|}{ Df } & Mean Square & F & Sig. \\
\hline & Sum of Squares & Df & .038 \\
\hline Between Groups & 178.282 & 1 & 178.282 & 4.477 & \\
\hline Within Groups & 2548.748 & 64 & 39.824 & & \\
\hline Total & 2727.030 & 65 & & & \\
\hline
\end{tabular}

Considering table IV, it can be found the significance value (sig.) less than $\alpha=$ $0.05(0.038<0.05)$ and $F_{\text {obs }}$ more than $F_{\text {table }}\left(F_{\text {obs }}=4.477>F_{\text {tabel }}=3.98\right)$. It can be concluded that $\mathrm{H}_{0}$ is not supported and $\mathrm{H}_{1}$ is not supported meaning that the hypothesis stating that there is a significantly different effect between problem-based learning model and jigsaw type of cooperative learning model with prezi aid on the students' economic learning outcome is supported.

The variance analysis advanced test is the follow-up of variance analysis when it shows that $\mathrm{H}_{0}$ is not supported. This test is intended to find out which treatment having more effect on the students' learning outcome using SPSS 22 software. The effect of the two learning models can be seen from the students' mean score.

\section{Descriptive}

TABLE V. RESULT OF ADVANCED TEST

\begin{tabular}{|c|c|c|c|c|}
\hline \multicolumn{5}{|c|}{ Learning Outcome } \\
\hline & $\mathrm{N}$ & Mean & Std. Deviation & Std. Error \\
\hline$\overline{\mathrm{PBL}}$ & 32 & 80.91 & 6.557 & 1.159 \\
\hline JIGSAW & 34 & 77.62 & 6.070 & 1.041 \\
\hline Total & 66 & 79.21 & 6.477 & .797 \\
\hline
\end{tabular}

Table V shows the mean scores of 80.91 for PBL learning model and 77.62 for jigsaw type of cooperative learning model. It indicates that PBL learning model with prezi aid affects positively and significantly the students' learning outcome compared with the jigsaw type of cooperative learning model with prezi aid.

This research suggests that the economic learning using problem-based learning model with prezi aid is better than that using jigsaw type of cooperative learning with prezi aid. The students taught with problem-based learning model with prezi aid obtain the mean score of learning outcome of 80.91 while those with jigsaw type of cooperative learning with prezi aid obtain score of 77.62. It can be concluded that the students taught using problem-based learning model with prezi aid have learning outcome higher than those using jigsaw type of cooperative learning with prezi aid.

It is in line with Hsu's [8] study finding that PBL learning model is very effective to be applied because it can enable the students solve the learning problem more actively. Chen and Chen [9] explain that PBL learning model with media aid will improve the students' learning outcome. Similarly, Gunantara, Suarjana, and Riastini [10] state that the use of problem-based learning model can improve the 
students' learning outcome. Stankunas, Czabanowska, Avery, Kalediene, and Babich [11] explain that PBL learning model is better and more effective in learning because the students can develop their communication, logical thinking skills, and etc.

The learning using PBL model will invite the students, either individually or in group, to develop their thinking and problem-solving skill, and make the students more independent. The main components of PBL learning model are: 1) question or stimulus, 2) interdisciplinary focus, 3) authentic investigation, 4) artifact production and exhibit, and 5) collaboration [12]. The use of problem-based learning (PBL) model can also make the students more active in either individual learning or in group discussion so that the students ask question, express opinion and give alternative solution to the problem more frequently.

The application of PBL learning model with Prezi media will facilitate the teacher and the students in the learning process. It means that teacher and students can use Prezi media in learning process. The presence of prezi media will make the learning process more attractive and effective. Perron and Stearns in Aljehani [13] explains that Prezi is a tool useful to store and to make a more attractive and effective digital presentation because of its ability of integrating visual, text, audio, video and animation component into one presentation.

Some factors enabling the PBL learning model with Prezi aid better than the jigsaw type of cooperative learning model with prezi aid are as follows:

1. Question or stimulus problem featured in video or visual form of prezi media featuring a variety of real life situations make the students understand better the material to be learnt.

2. Interdisciplinary focus to concentrate the subject of problem investigated selected to enable the students to explore many subjects.

3. Authentic investigation requiring the students to try finding a real solution to the real problem by identifying the problem, developing hypothesis, analyzing information and predicting thereby developing their thinking skill.

4. Product in the form of debate, report and video presented by students using prezi media thereby making the students expressing opinion or alternative answer to the problem bravely.

5. Collaboration or cooperation with other students in small group thereby motivating and involving the students to develop their social skill.

It can be concluded that in this research, the learning applying problem-based learning model with prezi aid is more effective than jigsaw type of cooperative learning model. Thus, the economic learning outcome of problem-based learning model with prezi aid is higher than that of jigsaw type of cooperative learning model with prezi aid.

\section{CONCLUSION}

There is a significant difference of learning outcome between problem-based learning and jigsaw type of cooperative learning models with prezi aid. The economic learning using problem-based learning model with prezi aid obtains learning outcome better than that using jigsaw type of cooperative learning model with prezi aid. It may be due to such factors as: problem based learning that can invite the students to be more active during learning process. The characteristics of 
problem-based learning model can lead the students to develop their thinking, problem solving skills and can make them the more independent learners. The use of problem-based learning model contribute to improving the students' activeness both in individual learning and in discussion in the class so that the students ask question and express opinion more actively in solving problem.

The application of problem-based learning with prezi aid facilitates the students in understanding learning material and can attract the students' attention in learning process. Thus, it is very appropriate for a teacher to use problem-based learning model with prezi aid in learning process in order to stimulate the students to learn more actively so that the learning process can run more efficiently and effectively, that in turn can improve the students' learning outcome, particularly in economic learning. Some factors explaining problem-based learning (PBL) model with prezi better than the jigsaw type of cooperative learning model are: (1) the presence of stimulating question or problem displayed in prezi media, (2) the presence of interdisciplinary focus, (3) the presence of authentic investigation, (4) the presence of product in the form of debate, report, and video represented by students through prezi media, and (5) the presence of collaboration or cooperation with other students.

\section{REFERENCES}

[1] Undang-Undang Republik Indonesia Nomor 20 Tahun 2003 Tentang Sistem Pendidikan Nasional.

[2] Asif, F. \& Imran, M. (2013). Prospective Teacher's Beliefs about Concepts of Teaching and Learning. International Journal of Multidiciplinary Academic Research, 1 (1), 1-14.

[3] Uno, H. B., \& Mohamad, N. (2011). Belajar dengan Pendekatan PAILKEM. Jakarta: Bumi Aksara.

[4] Prince, M. (2004). Does Active Learning Work? A Review of the Research. Journal of Engineering Education, 93 (3), 223-231.

[5] Wulandari, B., \& Surjono. H. D. (2013). Pengaruh Problem-Based Learning Terhadap Hasil Belajar Ditinjau dari Motivasi Belajar PLC di SMK. Jurnal Pendidikan Vokasi, 3 (2), 178-191.

[6] Lento, C. (2016). Promoting Active Learning in Introductory Financial Accounting through the Flipped Classroom Design. Journal of Applied Research in Higher Education, 8 (1), 72-87.

[7] Rusman. (2014). Model-Model Pembelajaran: Mengembangkan Profesionalisme Guru. Jakarta: Rajawali Pers.

[8] Hsu, C. (2016). The Effect of Problem-Based Learning on Learning Outcomes of Accounting Students. Asian Journal of Finance \& Accounting, 8(2), 135-154.

[9] Chen, C. \& Chen C. (2010). Problem-Based Learning Supported by Digital Archives: Case study of Taiwan Libraries' History Digital Library. The Electronic Library, 28 (1), 5-28.

[10] Gunantara, G., Suarjana. M., \& Riastini, P. N. (2014). Penerapan Model Pembelajaran Problem Based Learning untuk Meningkatkan Kemampuan Pemecahan Maslaah Matematika Siswa Kelas V. Jurnal Mimbar PGSD Univeritas Pendidikan Ganesha, 2 (1).

[11] Stankunas, M., Czabanowska, K., Avery, M., Kalediene, R., \& Babich, S. M. (2016). The Implementation of Problem-Based Learning in Health Service Management Training Programs. Leadership in Health Services, 29 (4), 392-401.

[12] Arends, R. I. (2004). Learning to Teach. New York: McGraw-Hill.

[13] Aljehani, W. M. A. (2015). Using Prezi Presentation Software to Enhance Vocabulary Learning of EFL Secondary School Students. Education Research International, 4 (4), 67-81. 